


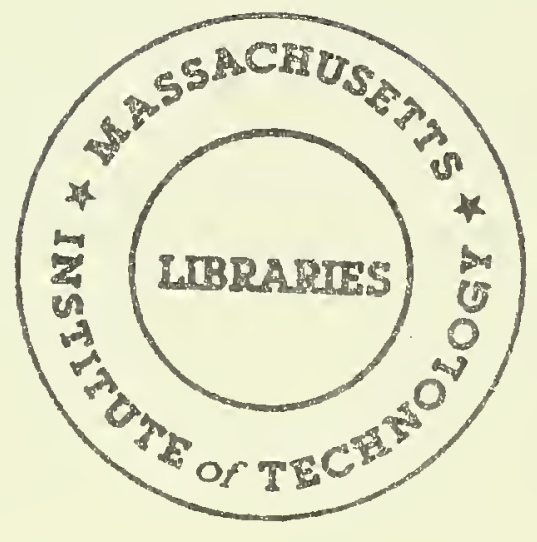


MLT. LIERARIES - OEMEY 



\section{working paper department of economics}

TAX INCENTIVES AND THE DECISION

TO PURCHASE HEALTH INSURANCE: EVIDENCE FROM THE SELF-EMPLOYED

Jonathan Gruber James Poterba

$94-10$

Feb. 1994

massachusetts institute of
technology

50 memorial drive cambridge, mass. 02139 


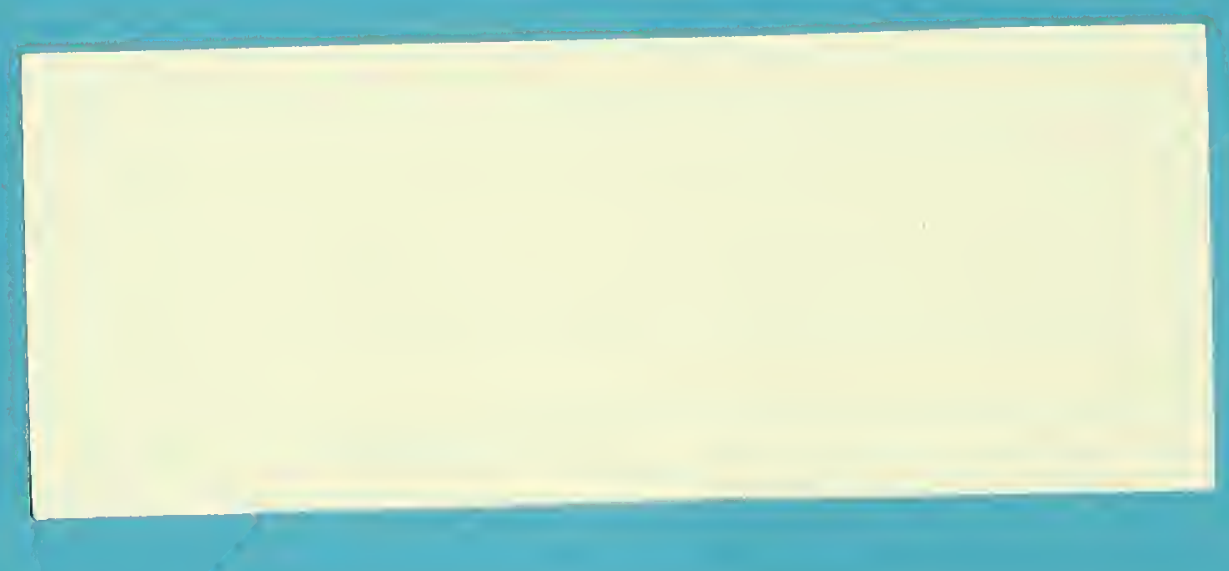


TAX INCENTIVES AND THE DECISION

TO PURCHASE HEALTH INSURANCE:

EVIDENCE FROM THE SELF-EMPLOYED

Jonathan Gruber

James Poterba

$94-10$

Feb. 1994 


M.I.T. LIBRARIES
JUL 121994
RECEIVED




\title{
TAX INCENTIVES AND THE DECISION TO PURCHASE HEALTH INSURANCE: EVIDENCE FROM THE SELF-EMPLOYED॰
}

\author{
Jonathan Gruber and James Poterba \\ MIT and NBER \\ July 1993 \\ Revised February 1994
}

The Tax Reform Act of 1986 introduced a new tax subsidy for health insurance purchases by the self-employed. We analyze the changing patterns of insurance demand before and after tax reform to generate new estimates of how the after-tax price of insurance affects the discrete choice of whether to buy insurance: We employ both traditional regression models and difference-indifference methods that compare changes in insurance coverage across groups around TRA86. The results from our most carefully controlled comparison suggest that a one percent increase in the cost of insurance coverage reduces the probability that a self-employed single person will be insured by 1.8 percentage points.

*We are grateful to Gary Engelhardt, Martin Feldstein, Victor Fuchs, Austan Goolsbee, Jerry Hausman, Lawrence Katz, Brigitte Madrian, Thomas McGuire, Joseph Newhouse, Douglas Staiger, John Shoven, Glenn Sueyoshi, Mark Wolfson, Richard Zeckhauser, two annonymous referees, and many seminar participants for helpful suggestions, to Todd Sinai and Aaron Yelowitz for expert assistance with the TAXSIM and SIPP tabulations, respectively, and to the Center for Advanced Study in Behavioral Sciences, the National Science Foundation, and the James Phillips Fund for research support. 
The value of employer-provided health insurance benefits is not included in an individual's taxable income. This is one of the most costly federal tax expenditures, accounting for an estimated revenue loss of nearly $\$ 50$ billion in 1993 . The resulting tax wedge between insurance and other forms of compensation, which may induce "overinsurance, " is often viewed as contributing to high and rising medical expenditures in the United States. Several recent proposals therefore call for capping the dollar value of health insurance benefits that can be excluded from taxation. Others, with the objective of lowering the number of uninsured persons, propose extending the tax incentive for health insurance to encourage insurance purchase.

The effect of these proposals depends critically on the price elasticity of demand for health insurance. If this elasticity is small, then limiting the tax expenditure on health insurance may raise substantial amounts of revenue but not have much effect on the extent of health insurance coverage, and proposals to expand insurance tax credits will have small effects in reducing the number of uninsured individuals. If the elasticity is large, however, tax policy will have large effects on the level of insurance coverage, but capping the employer deduction will raise less revenue. ${ }^{1}$

Because it is difficult to find exogenous sources of variation in insurance prices, there is little convincing empirical evidence on the price elasticity of demand for health insurance. Variation either through time or in a cross-section of households or firms reflects differences in the demand for health care as well as in the costs of providing this care. ${ }^{2}$ There are few shocks to the supply side of the health insurance market that are not potentially correlated with shocks to insurance demand and that can therefore identify the insurance demand curve. Tax changes provide a potentially exogenous source of variation in the after-tax price of health insurance. Two types of studies have tried to exploit this source of price variation. The first, exemplified by Long and Scott [1982], Vroman and Anderson [1984], and Turner [1987], examines how coverage changes as tax rates change over time. The fact, for example, that health insurance coverage has fallen in the 
1980s, as individual marginal tax rates have fallen, is taken as evidence that taxes affect the decision to insure. This correlation may be spurious, however, because other factors that affect the extent of health insurance coverage may have been changing as well. A large shift from industrial employment to service sector employment during the 1980s, rising real health care costs, and the widening income distribution may also have affected the demand for health insurance coverage.

Another approach to estimating the effect of taxes on coverage is to analyze a single crosssection of individuals or firms, and to ask whether those with higher tax-related subsidies to insurance purchase are more likely to be covered by health insurance or to spend more on insurance coverage. Studies of this second type include Taylor and Wilensky [1983], Woodbury [1983], Holmer [1984], and Sloan and Adameche [1986]. These studies face three important problems. First, differences in tax rates in a cross-section arise in part from differences in the underlying behavior of individuals or firms, such as through labor supply, family structure, or the nature of the workforce. It is difficult to tell whether differences in observed insurance coverage are due to taxes or these behavioral differences. Second, there is a basic problem in measuring the appropriate marginal tax rate for the wage-fringe decision at a firm. Since the workers at a single firm typically face a range of different marginal tax rates, the wage-fringe choice is a standard collective choice problem. It is impossible to escape arbitrary assumptions, such as imposition of a "median worker" rule, in measuring the change in the marginal tax rate that determines the wage-fringe mix at a firm. Finally, we shall argue below that many of these studies mis-specify the after-tax price of health insurance. $^{3}$

One notable line of research that avoids the problems with cross-section or time-series variation in after-tax insurance prices is the "experimental" approach, used for example by Marquis and Phelps [1987] and Thorpe et al. [1992]. Marquis and Phelps use evidence from the RAND 
Health Insurance Experiment to estimate a price elasticity of demand for supplementary insurance of -0.6 . Thorpe et al. estimated an elasticity in the range of -0.07 to -0.33 for small businesses that were offered a generous subsidy to the price of health insurance. It is not clear, however, whether such experimental evidence generalizes to evaluating the design of broad-based tax policies towards health insurance. ${ }^{4}$

In this paper, we exploit a new source of tax-induced variation in the effective price of health insurance: the 1986 change in the tax treatment of insurance purchases by self-employed individuals. Prior to the Tax Reform Act of 1986 (TRA86), self-employed individuals who did not itemize their income tax deductions paid for their health insurance with after-tax dollars. After TRA86, they could claim a tax deduction equal to 25 percent of their health insurance costs. We examine the effects of this tax-induced price change on the demand for health insurance by self-employed workers.

Our methodology avoids many of the confounding factors described above. First, by comparing the change in coverage for the self-employed to that of the employed, we can control for other changes in the economy that may have affected health insurance coverage. We show that the tax incentives for the purchase of health insurance by the employed changed very little around TRA86, so that they become a natural candidate to pick up other economy-wide trends. Second, by comparing similar self-employed individuals before and after the tax reform, we can control for other sources of demand variation that may be correlated with income or self-employment status. Finally, by looking at the self-employed, we avoid the problem of identifying "marginal" employees in large firms. A self-employed person is a firm's only employee. ${ }^{5}$

We use the Current Population Survey (CPS), a nationally representative survey of over 50,000 households that collects information each March on the respondent's insurance status in the 
previous year. Because the CPS does not collect data on insurance expenditures, our analysis focuses on the price-sensitivity of the discrete decision to purchase insurance. This is precisely the parameter that is central for evaluating proposals to use expanded tax incentives to increase insurance coverage among currently uninsured individuals.

Our study is divided into six sections. The first provides a detailed description of how the tax code affects the incentive to purchase insurance, with particular attention to the 1986 change in the after-tax price of health insurance for both the employed and self-employed. Section II outlines our modelling framework. The third section describes our data and discusses the insurance demand of the self-employed. In Section IV, we construct a measure of the after-tax price of health insurance, and report probit models of insurance demand for both self-employed and employed workers. These models parallel those that have been used in previous studies of how taxes affect the demand for fringe benefits, and our results confirm previous findings that changes in the after-tax price of insurance significantly affect insurance purchase decisions.

Section $\mathrm{V}$ explores this finding in more detail by comparing the changes in insurance demand over the 1985-1989 period between employed and self-employed individuals, as well as the changes in insurance coverage of high- and low-income self-employed and employed groups. In nearly all cases, these comparisons support the earlier finding that tax-induced reductions in the price of insurance raises the demand for insurance. A brief concluding section summarizes and interprets our findings, and suggests several directions for future work.

\section{Tax Incentives and the Relative Price of Insurance}

The tax system subsidizes expenditures on health care in several ways, thereby complicating the analysis of the tax incentive for insurance purchase. Individuals with employer-provided health 
insurance are not required to include the value of this insurance in their taxable income. Until 1986, the self-employed did not receive any comparable tax benefit if they purchased insurance. Taxpayers who claim itemized deductions can also deduct from their taxable income the portion of their expenditures on medical care and directly-purchased health insurance which exceed a certain fraction of their income from their taxable income. Thus, the tax deductibility of employer-provided health insurance premia does not in itself imply that the tax system subsidies insurance purchases because one alternative to insurance, direct payment of medical expenses, is also a deductible expense. A tax system that allowed equal deductions for both health insurance premia and medical expenses would provide no net subsidy to health insurance, although it would provide a substantial subsidy to health care expenditures.

To model the tax incentive for insurance purchase, we assume that an individual faces random medical costs with an expected value that we normalize to unity, and that these costs are independent of whether the individual is insured. ${ }^{6}$ The individual chooses between purchasing insurance which costs $(1+\lambda)$, where $\lambda$ is the policy's load factor, and paying for medical costs outof-pocket. If the tax code treats insurance premia and medical expenditures symmetrically, then the cost of insurance relative to the direct outlays on medical care is $q_{\text {ins }}=1+\lambda$. This is the benchmark case against which we evaluate the after-tax price of insurance in more complex cases.

\subsection{Employed Taxpayers}

We begin by analyzing the incentives for insurance purchase by an employed taxpayer who can purchase health insurance through his employer. Our exposition builds on the analysis by Phelps [1992]. There are three ways for this taxpayer to pay for medical care: with employer-provided insurance, with insurance purchased on own account, or with "self-insurance." We view this individual as the marginal worker who decides whether his employer will offer insurance, and 
assume for simplicity that both employer-provided and directly-purchased insurance policies have no deductible and a zero coinsurance rate. We focus on the average cost of insurance, and the average cost of self-insurance, rather than the marginal cost of an additional dollar of insurance expenditure because the data we analyze apply to the discrete choice of whether or not to purchase insurance. We denote marginal tax rate on earned income by $\tau$, the employer share of the payroll tax by $\tau_{s s}$, and the loading factor on employer-provided health insurance by $\lambda_{g}$; we assume that payroll taxes are borne in full by labor.

Employer-provided insurance strictly dominates insurance purchased on own account for both itemizing and non-itemizing taxpayers, due to the higher loading factors on individual policies, the full deductibility of employer-provided insurance expenditures relative to the partial deductibility of own insurance expenditures, and the deductibility of employer-provided health insurance from the payroll tax as well as the income tax. We therefore focus on the comparison between employerprovided insurance and self-insurance. When the employer purchases insurance at a cost of $\left(1+\lambda_{g}\right)$, the employee's wage is reduced by $\left(1+\lambda_{\mathrm{g}}\right) /\left(1+\tau_{\mathrm{sa}}\right)$. The employer is indifferent between purchasing one dollar of benefits or paying wages of $1 /\left(1+\tau_{\mathrm{ss}}\right)$, since each dollar of wages requires a payroll tax payment as well. The employee's after-tax wage therefore falls by $\left[\left(1-\tau-\tau_{\mathrm{ss}}\right) /\left(1+\tau_{\mathrm{ss}}\right)\right]^{*}\left(1+\lambda_{\mathrm{g}}\right)$. This expression measures the after-tax cost of insurance in terms of foregone wage income.

If an employed taxpayer does not buy insurance at all, his expected after-tax medical costs are $(1-\alpha \tau)$, where $\alpha$ indicates the expected fraction of medical expenses that will be deducted from taxable income. ${ }^{7}$ The after-tax price of employer-provided insurance relative to direct medical outlays is therefore

$$
\mathrm{q}_{\mathrm{ins}}{ }^{\prime}=\left[\left(1+\lambda_{\mathrm{g}}\right)\left(1-\tau-\tau_{\mathrm{ss}}\right)\right] /\left[\left(1+\tau_{\mathrm{ss}}\right)(1-\alpha \tau)\right] .
$$

Insurance load factors raise the price of insurance relative to self-insurance, in part offsetting the tax 
incentive to purchase insurance. The greater the fraction of medical expenses that a taxpayer expects to be able to deduct, the higher the relative price of insurance.

We define the tax-induced distortion in the relative price of insurance as the percentage change in the price of insurance as a result of the tax code:

$$
\theta=\left(\mathrm{q}_{\text {ins }}{ }^{\prime}-\mathrm{q}_{\text {ins }}\right) / \mathrm{q}_{\text {ins }}=\left(1-\tau-\tau_{\text {mos }}\right) /\left[\left(1+\tau_{\text {sos }}\right)(1-\alpha \tau)\right]-1
$$

where $\mathrm{q}_{\mathrm{ins}}=1+\lambda_{\mathrm{g}}$. To illustrate the magnitude of this distortion, consider a non-itemizing taxpayer who faces a federal marginal tax rate of 28 percent, a state tax rate net of federal deductibility of 5 percent (so $\tau=0.33$ ), $\tau_{s}=0.0765$, and assume that if the taxpayer does not itemize, a quarter of medical expenses will ultimately be deductible from taxable income ( $\alpha=.25$ ). In this case, $\theta=-0.399$, so the tax code effectively reduces the price of insurance by forty percent.

For the employed taxpayer, the Tax Reform Act of 1986 had two countervailing effects on the after-tax price of insurance. First, it lowered marginal tax rates substantially; the top rate on earned income dropped from 50 percent to 28 percent. Second, TRA86 made it more difficult to claim medical deductions, raising the non-deductible level of medical expenses from 5 percent to 7.5 percent of $\mathrm{AGI}$ and increasing the standard deduction, the amount that a taxpayer can deduct from taxable income if they decide not to itemize, from $\$ 3760$ to $\$ 5000$. In fact, the percent of tax returns claiming itemized medical deductions fell from $10.3 \%$ before TRA86, to $4.5 \%$ after the reform. The net effect of TRA86 on the price of insuring, relative to self-insuring, therefore depends on the particular circumstances of the employer taxpayer.

\subsection{Self-Employed Taxpayers}

Now consider a self-employed taxpayer who buys insurance in the individual market, at a price of $1+\lambda_{i}$, and deducts part of his health insurance cost $(\beta)$ as an itemized deduction. For these taxpayers, the after-tax cost of purchasing insurance before TRA86 was $(1-\beta \tau)\left(1+\lambda_{\mathrm{i}}\right)$, where $\beta=$ 
$\left[\left(1+\lambda_{i}\right)-F\right] /\left(1+\lambda_{i}\right)$ is the tax-deductible share of insurance costs. The parameter $F$ denotes the "floor" amount of spending on health costs that the taxpayer must incur before medical expenses become deductible. After TRA86, the after-tax cost became $\left(1-\max (\beta, .25)^{*} \tau\right)\left(1+\lambda_{i}\right)$, because onequarter of the premium could be deducted, but taxpayers could now only itemize the fraction of their insurance expenditures which were not taken as part of the general tax subsidy. For these itemizing self-employed taxpayers, the after-tax price of health insurance changed from $\mathrm{q}_{\mathrm{ins}}{ }^{\prime}=(1-\beta \tau)(1+\lambda) /(1$ $\alpha \tau)$ before TRA86, to $\mathrm{q}_{\text {ins }}{ }^{\prime}=\left(1-\max (\beta, .25)^{*} \tau\right)(1+\lambda) /(1-\alpha \tau)$ afterwards. The tax incentive for insurance purchase by this group was altered by the $25 \%$ tax subsidy, the changes in the thresholds for itemizing medical expenses (through $\alpha$ and $\beta$ ), and changes in marginal tax rates. Note that, for self-employed taxpayers with $\beta>.25$ both before and after TRA86, the health insurance deduction for the self-employed did not affect the tax subsidy to insurance.

\subsection{Calculating the After-Tax Price of Health Insurance}

To estimate $\alpha$, the expected fraction of medical expenses that a self-insured person-will be able to deduct from his taxes, and $\beta$, the expected fraction of insurance costs that will be deductible, we use data on the distribution of expenditures on both health care and privately-purchased insurance from the 1977 National Medical Care Expenditure Survey. We combine this information with data from the Treasury Department's Individual Tax Model, along with the NBER's TAXSIM program, to estimate the expected after-tax price of health insurance. Appendix A describes our algorithm in more detail.

Our estimates demonstrate that the 1986 Tax Reform Act subsidized insurance purchase by self-employed individuals, but had little effect on the incentive for employed persons to purchase insurance. Table I presents summary information on the average after-tax price of insurance, relative to self-insurance, for several years surrounding TRA86. The data are stratified into employed and 
self-employed, and also into groups based on household taxable income. The results show that for the self-employed, the average after-tax price of health insurance fell from 1.41 to 1.33 , while for employed individuals there was a trivial decline. The tax price reduction was most dramatic for high income self-employed individuals. We illustrate this by contrasting persons with incomes in excess of $\$ 50,000$ in $\$ 1985$ to those with real incomes below $\$ 20,000$. For the high income group, the tax price fell from 1.455 to 1.307 , while the fall for the low income self-employed was much smaller. There was little change for either high or low income employed persons.

Our finding of virtually no change in the relative price of insurance and self-insurance for the employed contrasts with the usual conclusion, presented for example in Woodbury and Hamermesh [1992], that falling marginal tax rates raised the cost of health insurance. TRA86 raised both the after-tax cost of employer-provided health insurance and the cost of self-insuring for medical expenses. While the tax change therefore raised the cost of purchasing health care, with or without insurance, it had little effect on the incentive to insure. If one were studying how TRA86 affected the total amount of health care purchased, the crucial relative price would be that for health services, a weighted average of the insured and self-insured costs, relative to all other goods. TRA86 raised this relative price.

\section{Modelling the Demand for Insurance}

We begin our study of TRA86 and insurance demand by specifying a discrete choice model of individual insurance demand, which follows previous studies such as Marquis and Phelps [1987]. We assume that an individual's underlying demand for health insurance, $\mathrm{I}_{\mathrm{i}}{ }^{*}$, can be described by a vector of socio-demographic characteristics $\mathrm{X}_{\mathrm{i}}$, income $\mathrm{Y}_{\mathrm{i}}$, and after-tax price of health insurance, $P_{i}:$ 


$$
I_{i}^{*}=X_{i} \beta+Y_{i} \alpha+P_{i} \gamma+\epsilon_{i} .
$$

In practice, $\mathrm{L}_{i}{ }^{*}$ is unobservable. We observe instead a dummy variable, defined by $I_{i}=1$ if $I_{i}^{*}>$ 0 , and $I_{i}=0$ otherwise. The insurance purchase decision exhibits a random component, and the probability that we will observe insurance coverage is

(4) $\operatorname{Prob}\left(I_{i}=1\right)=\operatorname{Prob}\left(I_{i}^{*}>0\right)=\operatorname{Prob}\left(\epsilon_{i}>-X_{i} \beta-Y_{i} \alpha-P_{i} \gamma\right)=1-F\left(-X_{i} \beta-Y_{i} \alpha-P_{i} \gamma\right)$, where $F$ is the cumulative distribution function for $\epsilon_{i}$. We assume that $\epsilon_{i}$ follows a normal distribution, and estimate the parameters in (3) by fitting a probit model to a pooled set of Current Population Survey data, including observations from before and after the Tax Reform Act of 1986.

This probit equation combines many different sources of variation in the price of health insurance. Some of this variation, particularly the cross-sectional variation in after-tax prices between households, will be correlated with other household attributes that may affect the demand for health insurance. Omitting these unobserved attributes from the estimating equation could lead to biased estimates of the price elasticity of insurance demand. An example can illustrate this problem. With a progressive tax code, a large number of children in a family lowers the household's marginal tax rate conditional on pre-tax income, since it increases the number of personal exemptions that can be claimed on the household's federal tax return. However, a large family may also demand more health insurance for other reasons. This source of cross-sectional variation in the after-tax cost of health insurance and the probability of purchasing health insurance could therefore yield an apparently positive relationship between tax price and demand. While one can try to control for such effects, there always remains a danger of spurious correlation. ${ }^{8}$

We can describe the three sources of identifying variation in our pooled CPS data sample:

(i) Cross Section: Employed vs. Self-Employed Workers, Each Year;

(ii) Cross Section: High- vs. Low-Marginal Tax Rate Workers, Each Year; 
(iii) Time Series: Before vs. After TRA86

Each is prone to yield spurious conclusions about the price elasticity of insurance demand in specifications where the tax rate is the only source of variation in the after-tax price of insurance. For example, the cross-sectional differences between employed and self-employed workers could easily be driven by unobserved differences in the tastes for risk of workers who do and do not decide to become self-employed. Cross-sectional differences in marginal tax rates within the employed and self-employed groups are largely the result of differences in income, family status, or other household decisions that may be correlated with tastes for insurance. The time series variation alone is potentially confounded by other shifts in insurance demand over this time period.

Combining these different sources of variation offers a more promising identification strategy. ${ }^{9}$ For example, while there may be a number of reasons why self-employed persons have a lower insurance coverage rate than employed persons in a cross-section, by examining the change in relative coverage rates across these groups from before to after TRA86, we can hold these other differences fixed. Similarly, by comparing high marginal tax rate self-employed persons to lowmarginal tax rate self-employed persons both before and after the subsidy is in place, we can control for cross-sectional differences in attributes that may be correlated with the tax rate. This is the essence of our modelling strategies below.

\section{Insurance Coverage Information in the Current Population Survey}

Each March, the Current Population Survey (CPS) asks respondents about their health insurance coverage in the previous year. The CPS includes information on employment status, job characteristics, and income in the previous year as well. We combine data from the 1986 and 1987 March CPSs to create a sample of individuals for the pre-tax reform period, and we combine the 
respondents in the March 1989 and 1990 CPSs to construct a post-tax reform sample. We exclude the March 1988 CPS, which collected data on insurance status in 1987 , because this was a transition year for tax rules. The pre-TRA sample therefore provides information on insurance coverage in 1985-1986, while the post-reform sample applies to 1988-1989.

The major advantage of the CPS for our purposes is that it is the largest annual survey that collects information on health insurance status. This large sample size may be important for examining groups, such as the self-employed, that constitute a small fraction of the population. The principal disadvantage of the CPS is that it does not include information on health insurance expenditures. Another disadvantage is that the CPS questionnaire was changed in March, 1988, in order to more accurately capture the insurance coverage of dependents. Previous surveys asked each household member over fifteen years old if he had insurance in his own name, and if so, who else in the household was covered by this policy. For household members without insurance in their own name, coverage was imputed based on the responses of others in the household. Beginning in March 1988, each household member was asked if he was covered by insurance, and if so, whether it was in his own name and who else it covered. This change meant that dependents who had coverage from outside the household, previously labelled uninsured, were now recorded as insured.

This survey change implies that insurance coverage rates of dependents may be changing spuriously over this time. We minimize this problem in our analysis by focusing on persons aged 25-54, since this is the group which the Census Bureau [1988] notes is the least likely to be affected by the CPS questionnaire change. ${ }^{10}$ The change also implies that we are unable to examine insurance coverage in an individual's own name, since the survey responses are not consistent over time. Instead, we focus on coverage from private health insurance either in one's own name or in someone else's. This could affect our results if there were changes in insurance coverage from the self- 
employed's other family members, particularly their spouse, coincident with TRA86. In the results below, we therefore examine single and married individuals separately, since most insured single individuals have coverage in their own names. ${ }^{11}$

Table II presents the characteristics of our sample. Individuals are classified as self-employed if they report themselves to be self-employed based on their main job last year and if they report at least $\$ 2000$ (\$1985) in self-employment income. The latter restriction is used because the health insurance deduction was limited to the amount of self-employment income earned by the individual. Thus, we exclude persons with only occasional self-employment earnings from our sample. Employed persons are those who report themselves to be employed, report no self-employment earnings, and also earn at least $\$ 2000$ in wages and salaries.

Relative to the employed, the self-employed are slightly more educated and older (experience is defined as age minus education minus 6), are less likely to be female or black, are roughly equally wealthy, and are less likely to be in sales or manufacturing. There is little change in the characteristics of the employed sample over time. For the self-employed, there is an increase in the percentage that are female and in average family income, but other characteristics appear similar over this time period. The working uninsured resemble the employed more than the self-employed in terms of demographic characteristics, but in terms of occupational and industrial distribution they are more similar to the self-employed.

Table III presents background information on the incidence of insurance coverage for both employed and self-employed workers before and after TRA86. ${ }^{12}$ The sample is disaggregated by marital status, to provide some information on the potential confounding effects of spousal coverage, and by tax filing unit income. Tax filing units are defined in the CPS as heads of families, spouses, and any dependents who are younger than 19 or are students. 
Table III illustrates five important phenomena. First, the rate of private insurance coverage among self-employed persons is quite low; it averages $69.4 \%$ before TRA86, and is only $50 \%$ for single self-employed persons. This suggests the potential for a large response of the self-employed to government tax subsidies for health insurance. Second, the probability of insurance coverage for all groups rises sharply with income. Third, the rate of insurance coverage for employed persons is higher than that of self-employed persons at all except the lowest income levels. Fourth, coverage rises more rapidly with income for employed persons than for self-employed persons. This set of pre-TRA 86 facts is consistent with the presence of a tax subsidy to the employed that becomes more valuable as incomes and tax rates rise.

The fifth finding in Table III is a increase in the rate of insurance coverage among selfemployed workers between the pre-TRA86 and post-TRA86 periods, and a coincident decline in the rate of coverage for employed workers. This pattern is evident for the disaggregated groups of single and married individuals, and for most of the disaggregated income categories as well. ${ }^{13}$ This change in relative insurance coverage rates for employed and self-employed workers around the Tax Reform Act of 1986 does not reflect a long-term pattern of shifting insurance coverage during the 1980s. Table IV shows CPS-based insurance coverage rates for employed and self-employed individuals for the 1982-1990 period. The coverage rates for single employed and self-employed workers in the 1982-1986 period show downward trends. For the whole population, there is no evident trend in the coverage rate among the self-employed, and weak evidence of a declining trend for the employed.

\section{Estimates of Insurance Demand Equations}

Table V presents estimates of probit models such as specification (4) above. The models 
relate insurance coverage to income and the after-tax price of insurance. Each equation controls for a detailed set of individual and job characteristics: potential experience; education; indicator variables for gender, marital status, and non-white; controls for part time ( $<35$ hours/week of work), less than half-time ( $<18$ hours/week), and part-year ( $<26$ weeks of work in the preceding year); the $\log$ of tax unit income; self-employment status; four year dummies; and 15 major industry dummies. $^{14}$

The first column presents the estimates from a regression that excludes the tax cost variable. Column two shows the marginal effects of each coefficient. ${ }^{15}$ The results are broadly consistent with prior studies of insurance coverage. Insurance coverage rises with experience, education, and marriage, is higher among white than non-white workers, and is higher for full time than less-thanfull time workers. Higher income families are much more likely to have insurance coverage, and the self-employed are much less likely to be covered. These two findings may be the result of the tax subsidy to employer provided health insurance, which becomes more valuable as income rises and is either non-existent (before TRA86) or less valuable (after TRA86) for the self-employed.

The after-tax price of insurance is included in the equation reported in column (3). Since the majority of the control variables do not change when the tax price is added to the regression, the full set of marginal probabilities is not presented here. The tax price has a highly significant coefficient, suggesting that higher after-tax prices reduce insurance coverage. We interpret our coefficient estimates by calculating the derivative of the probability of insurance coverage with respect to the after-tax price of insurance. The implied derivative in the third column of Table 4 is approximately -0.3. A more natural parameter is the semi-elasticity of insurance coverage with respect to the aftertax price of insurance, ie. the number of percentage points that the insured fraction of the population would change by if the after-tax price of insurance rose by one percent. To compute this semi- 
elasticity we multiply the estimated derivative by 0.96 , which is approximately the average after-tax price of insurance in our data. This yields a semi-elasticity of $-0.252 .^{16}$

One potential problem with this specification is that the tax cost may simply be capturing a second-order income effect, since the tax price itself depends on income in a nonlinear way. We attempted to control for this by replacing the log of family income with an exhaustive set of indicator variables for households in each $\$ 1000$ income bracket. The estimated coefficients for both the entire sample and the self-employed only fell slightly, and remained sizeable and significant. This is consistent with the fact that the full set of dummies explains only 2.5 percent more of the variation in the tax price than the log of tax filing unit income.

While measuring tax price using the individual's tax rate may be appropriate for the selfemployed, it is more problematic for employed persons, since insurance coverage for this group partly reflects the demands of a collection of workers at a firm, not just the individual worker we observe in the CPS. We therefore construct an alternative measure of the after-tax price for employed workers as the average value of the after-tax price for workers in their industry and occupation cell. ${ }^{17}$ The results in column four replace the tax price for employed workers with this "grouped" tax price. The estimated derivative of coverage with respect to the price of insurance approximately doubles and the implied semi-elasticity is now -0.425 .

This rise in the price effect may be the result of a reduction in the error with which the relevant marginal tax price for the employed is measured. Measurement error in the tax price can arise either the collective choice problem discussed above, or from errors induced by our imputation of the individual's tax rate. If this measurement error averages to zero in a broad industry/occupation group, then the grouped regressions will be free of such error. Angrist [1991] develops this argument in the context of labor supply. 


\section{5. "Differences in Differences" Estimates of Price Effects on Insurance Demand}

The estimates above suggest that the after tax price of insurance affects the probability that a household will purchase insurance. Yet they do not provide any direct evidence on how households responded to the Tax Reform Act of 1986. The empirical tests in this section focus on the effects of particular sources of variation in the after-tax price of health insurance.

\subsection{Employed vs. Self-Employed Workers, Pre- and Post-TRA86}

The first source of variation that can be used to identify the price elasticity is the change in insurance coverage among self-employed persons, relative to employed persons, over the period when TRA86 took effect. We noted above that the tax price for self-employed workers fell, while that for employed workers was unchanged as a result of TRA86. We would therefore expect an increase in the insurance coverage rate of self-employed as opposed to employed workers coincident with the tax reform.

There are many reasons why self-employed individuals may have lower insurance rates than employed persons, one of which is the lack of a tax subsidy for health insurance before 1986 . By studying the difference in insurance coverage rates for this group over time, however, we can control for any time invariant factors in their insurance demand. Furthermore, we can compare this time difference to the change in insurance coverage among employed individuals, to control for time series trends in economy-wide insurance demand, including the income effects of TRA86. Under the assumption that there are no non-tax shocks to only one of these groups, the result is a "differencesin-differences" estimate that can be labelled the effect of the taxes on insurance demand. ${ }^{18}$

Table VI presents summary statistics on insurance demand for these groups, without controlling for any other factors. Each cell contains the private insurance coverage rate among the group labelled on the axes, and the standard errors are shown in parentheses. The first row of Table 
6 shows that insurance coverage for the self-employed rose by $4 \%$ between 1985-6 and 1988-9. At the same time, coverage fell significantly for the employed, despite a lack of change in their tax incentives. This suggests that other economy-wide trends led to lower demand for insurance over this time period. Using the experience of the employed as a control for these trends, we find a net rise in the coverage of the self-employed of $6.8 \%$ during the TRA86 enactment period. This is consistent with TRA86 raising insurance purchase by the self-employed relative to the employed.

There is a potential problem with this identification strategy: the composition of the employed and self-employed groups may have been changing over time. Devine [1992] reports that there was an increase in CPS-based self-employment rates beginning around 1986; our analysis confirms this. ${ }^{19}$ If the new self-employed individuals had a higher propensity to be insured than the previous self-employed, then compositional changes could contribute to rising insurance rates. However, even if the new self-employed were as likely to be insured as the average employed worker, the resulting compositional shift can explain only about $10 \%$ of the relative shift in insurance rates for employed and self-employed workers that we observe. We also evaluated the importance of such compositional shifts by comparing the self-employed before and after TRA86. The observable characteristics of the self-employed in the CPS after the Tax Reform Act are quite similar to those of the group we observe before the Act. ${ }^{20}$

To further control for the possibility that the differences in insurance probabilities reported in Table VI are due to changes in the characteristics of the self-employed or employed groups between 1985-6 and 1988-9, we also estimate probit models for insurance demand that control for these characteristics. We begin with an equation of the form:

$$
\mathrm{I}_{\mathrm{i}}^{*}=\mathrm{X}_{\mathrm{i}} \beta+\mathrm{Y}_{\mathrm{i}} \alpha+\operatorname{SELF}_{\mathrm{i} * \delta_{1}}+\operatorname{POST}_{\mathrm{i}}^{*} \delta_{2}+\operatorname{SELF}_{\mathrm{i}}^{*} \operatorname{POST} 6_{\mathrm{i}}^{*} \delta_{3}+\epsilon_{\mathrm{i}} .
$$

SELF $_{i}$ is set equal to one if the worker is self-employed, and is zero otherwise. POST86 is set to 
one for years after 1986, and is zero previously. In this framework, POST86, and SELF control $_{i}$ for the general time series trend in insurance coverage and the secular demand effect of being selfemployed, respectively. The interaction, POST86 ${ }^{*} \operatorname{SELF}_{\mathrm{i}}$, captures the change in demand for the self-employed, relative to the employed, after TRA86. The estimate of $\delta_{3}$ indicates whether the insurance coverage rate for self-employed workers changed more after 1986 than did the coverage rate for employed workers. Even if there were no relative changes in group characteristics, controlling for individual covariates can reduce the sampling variance of the differences-indifferences estimator.

Table VII reports only the coefficients of interest, such as $\delta_{3}$, from equation (5). The coefficients on the other included explanatory variables are similar to those in Table 5. The top panel of Table VII presents the results of estimating equation (5) for the entire data sample as well as for single and married individuals separately. We present the probit coefficients and their associated standard errors, the marginal effect of the interaction on the probability of insurance coverage, and the implied estimate of the derivative of demand with respect to the tax price. Derivatives are calculated using the probit marginal effects from this regression in the numerator, and the difference-in-difference of the average tax cost for each cell in the denominator. These figures can be converted to semi-elasticities by multiplying by 1.37 , the average after-tax price of health insurance for self-employed individuals in our sample. ${ }^{21}$

The results in the first panel of Table VIl confirm the conclusions from in Table 5. The difference-in-difference estimate of the effect of the tax subsidy is sizable and statistically significant. The magnitude is about three-fifths of the estimate from Table 6, implying a price derivative of -0.5 , and a semi-elasticity of -0.685 . This finding is similar to the result from the probit equations in Table 5, for the case when the after-tax price for employed individuals was measured using group 
average marginal tax rates. The second and third columns of Table 7 present estimates for single and married workers separately. We distinguish these groups because the TRA86 experiment is much weaker for the married group, who may be covered by their spouse's health insurance, and thus may not be responding to the incentives put in place by the law change. ${ }^{22}$ While the estimated price elasticity is large and statistically significant for both groups, it is approximately $40 \%$ larger for single persons, which is consistent with this interpretation. ${ }^{23}$

Although our analysis relies primarily on CPS data to assess changes in insurance coverage surrounding TRA86, we have also explored the robustness of our findings using the Survey of Income and Program Participation (SIPP). The SIPP is a nationally representative longitudinal survey which follows respondents for 28-32 months, and collects information on both labor force attachment and health insurance. Its most important virtue, from our perspective, is that the question on health insurance coverage did not change during this time period, so that we can surmount this difficulty with the CPS. Its primary disadvantage, however, is that sample sizes are much smaller than those in the CPS, so that the precision of our estimated insurance coverage rates is lower. We use information from the fourth wave of the 1984 survey and the seventh wave of the 1986 survey, which collected point in time information on insurance coverage for spring 1985 and 1988.

The changes in insurance coverage that result from comparing the 1985 and 1988 SIPP data support our CPS-based conclusions. In 1985 , we estimate that 82.4 percent of the self employed were covered by insurance, with a standard error of 10.3 percent. For employed, the insurance coverage rate is 89.3 percent $(0.3)$. In the 1988 data, 85.3 percent $(15.8)$ of self-employed workers reported insurance coverage, compared with 89.0 percent (0.4) of employed workers. The difference-in-difference estimator for the change in insurance coverage is therefore $3.2 \%$ (1.6\%). 


\subsection{High-Income versus Low-Income Self-Employed Workers, Pre- and Post-TRA86}

A second component of insurance price variation is due to different marginal tax rates within the self-employed group. The post-1986 deduction should be more valuable to higher income selfemployed individuals than to lower income self-employed individuals, since the marginal tax rate for the former group is higher. We test the effect of TRA86 on different groups of self-employed workers by estimating another differences-in-differences probit model, this time for self-employed workers only. The basic specification is:

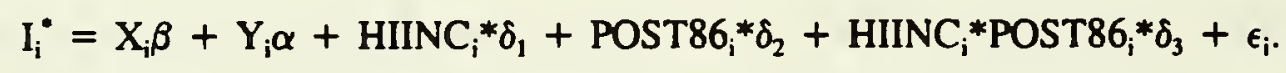

HIINC is set equal to one for individuals with over $\$ 50,000$ in real family income, and zero for individuals with less than $\$ 20,000$ in real family income. ${ }^{24}$ The estimated coefficient on the HIINC*POST86 interaction term, $\delta_{3}$, now tests whether insurance coverage rose more among the high-income self-employed than their lower-income counterparts. Once again, this framework allows us to control for both time series trends in demand among the self-employed, and for fixed characteristics of high and low income self-employed that may affect their demand. To the extent that the earlier finding of a relative rise in coverage for the self-employed is an artifact of a change in the market for insurance by employment status, then this model provides an independent test of the effect of the tax reform on insurance demand.

The second panel of Table VII presents the results of estimating equation (6). We again find a statistically significant effect of the tax subsidy, and the implied price derivative of demand, -0.37 , is similar to that of the previous case. It is much larger for single self-employed workers, and smaller for the married self-employed. The larger magnitude of the estimated price effect for the single self-employed in this specification than in the first differences-in-differences specification may be a function of differential take-up rates for the health insurance deduction. Tax return data from 
1989 suggest that the probability of claiming the health insurance deduction rose with income, which will impart an upward bias to the estimated price effect in our second differences-in-differences estimation. The true price effect lies somewhere in between the two estimates. ${ }^{25}$

5.3 High versus Low Income Self-Employed, versus High versus Low Income Employed, Pre/PostTRA86

The previous difference-in-difference regression is identified by the assumption that non-tax factors causing insurance demand changes by income class are not correlated with tax changes by income class. This may be an untenable assumption given the nearly linear relationship between tax changes and income in an era when several researchers, for example Katz and Murphy [1992], have documented changing opportunities between the-rich and poor. A natural test for whether non-tax factors affecting insurance demand changes by income class pose a problem is to compare our difference-in-difference estimates for the self-employed to similar estimates for the employed. We estimate that TRA86 should have had little impact on the health insurance demand of the high-income employed relative to the low-income employed, since the decline in marginal tax rates at the top of the income scale is compensated for by the fall in the tax subsidy to self-insuring for that group. Therefore, if we were to find a relative rise for high-income employed workers as well, it would suggest that factors other than TRA86, such as an economy-wide shock to insurance demand at high incomes, might explain our findings for the self-employed group.

In fact, Table IIl showed that insurance coverage rates rise with income for the employed as well as the self-employed. Furthermore, regressions similar to (5) for the employed yield significant positive estimates of $\delta_{3}$, which appears to be driven by a drop in insurance coverage at low incomes rather than a rise at high incomes, as for the self-employed.

To assess the implications of this finding for our results, we can move to a "differences-in- 
differences-in-differences" framework, as in Gruber [1994], where the change by income class for the employed is viewed as a control for economy-wide trends in demand by high- and low-income persons. One can therefore ask whether the difference in the rate of coverage growth between highincome and low-income self-employed was larger than that for corresponding income groups among employed persons. We do so by estimating the following probit model for the entire employed and self-employed sample:

$$
\begin{aligned}
& \mathrm{I}_{\mathrm{i}}^{*}=\mathrm{X}_{\mathrm{i}} \beta+\mathrm{Y}_{\mathrm{i}} \alpha+\mathrm{HIINC}_{\mathrm{i}}^{*} \delta_{1}+\mathrm{POST}_{\mathrm{i}}{ }^{*} \delta_{2}+\mathrm{HIINC}_{\mathrm{i}}{ }^{*} \mathrm{POST} 6_{\mathrm{i}}^{*} \delta_{3}+\mathrm{SELF}_{\mathrm{i}}{ }^{*} \delta_{4}
\end{aligned}
$$

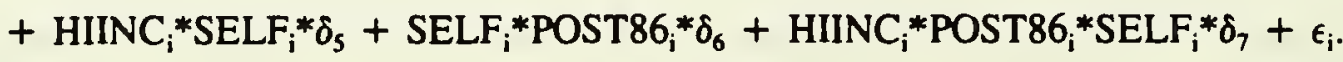

As in the earlier specifications, this model includes controls for the secular demand effects of being self-employed (SELF) or high income (HINC), and for general time series trends in demand (POST86). The second level interactions control for changes in the demand for insurance among high vs. low income groups (HIINC*POST86), changes in demand for the self-employed relative to the employed SELF*POST86), and differences in demand among the high-income self-employed relative to the low-income self-employed (HIINC*SELF). All that remains to identify the effect of the subsidy is the effect on the high-income (relative to the low-income) self-employed (relative to the employed) after TRA86 (relative to before TRA86); this is the term HIINC*POST86*SELF.

The bottom panel of Table VII reports estimates of equation (7). The price derivative estimates are reduced by about 50 percent relative to earlier estimates. For the entire sample, the estimate of $\delta_{7}$ is negative but only significant at the 10 percent level; the implied semi-elasticity is 0.334 . When this model is estimated on the sample of single persons, however, the results are statistically significant and the point estimate is negative, with an implied price derivative of insurance purchase of about -1.3 and a semi-elasticity of -1.78 . For the sub-sample of married persons, the group that we view as yielding a weaker "experiment" because of the presence of 
spousal coverage, the estimated effect is negative but statistically insignificantly different from zero.

These results suggest that, for the full sample of workers, the economy-wide trend towards increased insurance coverage for higher income classes may weaken the second of our differences-indifferences tests used above. However, for single workers, the group for whom our experiment is most well defined, there remains strong evidence of a response to the tax subsidy.

\section{Conclusions}

The Tax Reform Act of 1986 extended a partial income tax deduction for health insurance costs to self-employed workers, bringing them closer to the tax treatment afforded to employerprovided health insurance. We compare the change in health insurance coverage for the selfemployed with that of employed workers and find strong support for a negative price elasticity of demand for insurance coverage. The results from our most carefully controlled comparison, which focuses on insurance demand among unmarried individuals, suggest that a one percent increase in the cost of insurance coverage reduces the probability that a self-employed household will be insured by 1.8 percentage points. While the precise estimates of the elasticity are somewhat dependent on other aspects of the econometric specification, the general direction of our findings is very robust to our choice of specification.

One potential limitation of our analysis is our relatively small set of control variables for characteristics of the employed and self-employed that might affect their demand for health insurance. If the distributions of the unobserved characteristics of these groups remain constant over time, the presence of unobservables should not contaminate our findings. If the TRA86 tax subsidy to health insurance for the self employed induced some previously employed workers with high health insurance demand to become self employed, or if other aspects of TRA86 or coincident shocks 
altered the characteristics of the self-employed in a systematic way, this could affect our results. We have not found any evidence, however, to suggest the importance of such contaminating factors.

A second limitation of our analysis is our focus on the discrete decision of whether or not to purchase insurance, rather than the quantity of insurance to purchase. This focus, which was dictated by our data set, implies that our estimates may be more relevant for the design of tax subsidies to increase coverage among the uninsured than for the evaluation of limits on the tax deductibility of employer-provided health insurance. Future research could usefully extend the type of methodology explored here to estimate the price elasticity of the quantity of insurance demanded, in order to answer questions such as how the level of insurance demand amongst currently insured individuals will change if the tax code allows partial deductibility of health insurance outlays.

Furthermore, discrete decisions such as whether or not to become insured may be susceptible to "recognition effects." When a new policy, like TRA86, provides an incentive for insurance, individuals may evaluate their insurance status and decide to buy insurance. Thus, it may have been the presence of the subsidy itself, and not its magnitude, which was key in driving the increase in insurance demand among the self-employed. It would be fruitful to extend this line of research in an effort to disentangle steady state demand elasticities from such "recognition effects". 


\section{APPENDIX A: CALCULATING THE AFTER-TAX PRICE OF INSURANCE}

This appendix describes our calculation of the after-tax price of insurance coverage for each person in the CPS. The CPS reports data on individuals, families, and households, but not on tax filing units; these units may be smaller than families, if the family unit includes individuals who are filing their own returns. We used the simple rule that individuals are considered part of a tax filing unit if they are the head of the family, the spouse, or a dependent who is younger than 19 or is enrolled in school. For each of these tax filing units, we extracted data on: filing status (single if not married and no children; joint if married; head of household if unmarried with children); number of dependents; wage and salary income; dividend and interest income; self-employment income; farm income; and other income.

We then computed marginal tax rates for each of our tax filing units using the NBER's TAXSIM calculator. TAXSIM takes as input all of the detailed information that is reported on individual tax returns. The CPS data are missing a number of important items that are reported on tax returns, most notably itemized deductions and capital gains. We therefore used the Treasury Individual Tax Model data file, which contains over 70,000 tax filing units, to impute each tax filing unit's probabilities of itemizing and declaring capital gains, as well as the amounts of deductions and capital gains conditional on having them.

Our imputation algorithm employed Treasury Tax Model data for 1986 and 1988 . We applied data for these years to 1985 and 1989 by inflating or deflating monetary amounts using the Consumer Price Index. We imputed information to individuals by assigning each CPS observation to one of 64 classifications: 16 income classifications, by two filing status classifications (single and joint, with head of household in the former), by two self-employment classifications (schedule C income $>0$ and schedule $\mathrm{C}$ income $<=0$ ). In each classification, we assigned individuals the 
average amount of itemized deductions and capital gains income reported by taxpayers in that classification with non-zero amounts. We also assigned the average probabilities of itemizing deductions and realizing capital gains for each classification. We then imputed four possible tax rates for each tax filing unit, corresponding to: (1) No itemization, no capital gains; (2) Itemization, no capital gains; (3) No itemization, capital gains; and (4) Itemization and capital gains. The tax rate we use in our regressions is a weighted average of these four rates, where the weights are the imputed probabilities of itemizing or declaring capital gains in each classification.

The after-tax price of health insurance must account for the relative tax treatment of health insurance and out-of-pocket expenditures on health care. We compute the average tax price using the following formulas for the self-employed and employed:

$$
\begin{gathered}
P_{S E}=\frac{\left[\left(1+\lambda_{i}\right)^{*} I /(I+O)+O /(I+O)\right]^{*}\left(1-\beta^{\prime} \tau\right)}{1-\alpha \tau} \\
P_{E}=\frac{(G / T) *\left[\left(1+\lambda_{B}\right) *\left(1-\tau-\tau_{m}\right) /\left(1+\tau_{e}\right)\right]+(1-G / T) *\left[\left(1+\lambda_{B}\right) * I /(I+O)+O /(I+O)\right]^{*}(1-\gamma \tau)}{1-\alpha \tau}
\end{gathered}
$$

where $\lambda_{\mathrm{i}}$ and $\lambda_{\mathrm{g}}$ are the loading factors on individual and group health insurance, respectively, $I$ is out-of-pocket spending on insurance, $O$ is out-of-pocket spending on health care services, $G$ is employer spending on group health insurance, $\mathrm{T}$ is total insurance spending and health care services spending, and $\beta^{\prime}, \alpha, \gamma$ are parameters that depend on the tax system and the distribution of health care spending. $\alpha$ is defined in the text, $\beta^{\prime}$ equals $\max (\beta, 0.25)$ for years after TRA86, and $\gamma$ is defined below.

The numerator of each price formula reflects the tax adjusted price of purchasing health insurance. A self-employed person pays the individual insurance loading factor on the portion of her health care spending that is on insurance, but no loading factor on out-of-pocket medical expenditures. The average self-employed person can expect that a fraction $\beta$ ' of her expenditures 
on insurance and health care services will either lie above the threshold for tax itemization, or be subject to the $25 \%$ tax subsidy. Thus, the net cost of their medical spending is only $\left(1-\beta^{\prime} \tau\right)$ of the initial dollar outlay.

For the employed person, the calculation is complicated by the fact that the employer's expenditures made on his behalf $(G)$ are fully tax deductible. Thus, for the fraction $G / T$ of health spending, the after-tax price is only $\left(1-\tau-\tau_{m}\right) /\left(1+\tau_{m}\right)$ per dollar of spending. The remainder of his expenditures consist of his expenditures on health insurance and out-of-pocket medical services. We assume that he can purchase insurance at the same group loading factor $\left(\lambda_{z}\right)$ and that his insurance expenditures are not tax deductible. The average employed person with employer-provided insurance expects that a fraction $\gamma$ of his own spending on insurance and health services will lie above the itemization threshold.

The denominators of $P_{S E}$ and $P_{E}$ reflect the cost of self-insuring. There is no loading factor on self-insurance, and the costs of medical care are reduced by $\alpha$, the fraction of those costs that the taxpayer expects to be able to itemize.

The key parameters for estimating the after-tax price of insurance are $\lambda_{i}, \lambda_{b}, \beta, \gamma$, and $\alpha$. The first two parameters can be estimated using data on group and individual insurance premiums and claims experience, from HIAA (1991). The last three parameters represent the expected fraction of insurance and medical spending that can be itemized by the self-employed insured, the employed insured, and the self-insured, respectively. We estimate them by assuming that the average person choosing between these categories expects to itemize the same fraction of expenditures as those currently in each category. We then estimate these fractions using information on the distribution of medical and insurance spending from the 1977 National Medical Care Expenditure Survey (NMCES), inflated to 1986 and 1988 levels using the medical care CPI. We then divide the 
NMCES into three subsamples of families: those in which both the head and the spouse are uninsured; those in which both the head and spouse have non-employer provided health insurance; and those in which either the head or the spouse has employer-provided health insurance. Each group is then further divided into three income categories and four categories of family structure. ${ }^{26}$

For each subgroup, we calculate the amount of their spending that can be claimed as an itemized deduction as:

$$
D E D=\max \left[I+O-f^{*} Y-S D^{*} P I, 0\right]
$$

where $f$ is the fraction of AGI which medical expenditures must exceed in order to be itemized, $Y$ is family income, $I$ is spending on insurance for those who purchase insurance on own account, $O$ denotes own-spending on medical care, SD is the standard deduction, and PI is the average probability of itemization in the subgroup. The final component of this sum, the expected value of the standard deduction, is an approximation to the loss of the standard deduction in excess of the taxpayer's other itemized deductions.

The fraction of medical spending that is itemized depends on the level of such spending, the AGI floor that such spending must exceed in order to be itemized, and the standard deduction. Tax reforms such as TRA86, which raised the AGI floor from $5 \%$ to $7.5 \%$ and increased the standard deduction, reduce the share of health care outlays that can be itemized. This affects the after-tax price of health insurance.

Finally, for each subgroup in each year, we estimate total deductible spending and divide this by the total spending in the subgroup. This yields our estimates of $\beta$ (from the purchasers of non employer-provided health insurance), $\gamma$ (from the employer-insured), and $\alpha$ (from the uninsured). For 1988 , we increase the numerator in the calculation of $\beta$ by $0.25 *$ total spending, in order to reflect the $25 \%$ tax subsidy to the self-employed. The results for each parameter are: 
Parameter

$\beta$,

$\gamma$

0.089
$(0.054)$

$\alpha$

1986

0.152

\subsection{7}

1988

(0.096)

0.304

(0.065)

0.041

(0.067)

(0.116)
0.100

(0.102)

Both $\alpha$ and $\gamma$ fall from 1986 to 1988 , as both the AGI floor and the standard deduction increase. $\beta^{\prime}$ increases, however, as the $25 \%$ subsidy more than compensates for these effects for the self-employed. These parameter values are used to calculated the after-tax price of health insurance for each individual in the CPS using our formulae for $P_{S E}$ and $P_{E}$.

Massachusetts Institute of Technology and National Bureau of Economic Research 


\section{References}

Adamche, Killard and Frank, Sloan, "Fringe Benefits: To Tax or Not To Tax?," National Tax Journal ,XXLVl (1985), 47-64.

Angrist, Joshua, "The Effect of Veteran's Benefits on Veteran's Education and Earnings," Industrial and Labor Relations Review, IVL (1993), 637-652.

Angrist, Joshua, "Grouped Data Estimation and Testing in Simple Labor Supply Models, " Journal of Econometrics, IIIL (1991), 243-266.

Bureau of the Census, "User Note: Modification to the March 1988 CPS Health Insurance Question: Some Preliminary Results." Washington: Bureau of the Census. (1988).

Burtless, Gary, and Larry Orr, "Are Classical Experiments Needed for Manpower Policy?," Journal of Human Resources, XXI (1985). 606-639.

Card, David, "The Effects of Minimum Wage Legislation: A Case Study of California, 1987-89," Industrial and Labor Relations Review, IVL (1992), 38-54.

Devine, Theresa, "The Recent Rise in U.S. Self-Employment," mimeo Pennsylvania State University. (1993).

Feenberg, Daniel, "Are Tax Price Models Really Identified: The Case of Charitable Giving," National Tax Journal, XL (1987), 629-633.

Feldstein, Martin S., "The Welfare Loss of Excess Health Insurance," Journal of Political Economy, LXXXI (1973), 251-280.

Gruber, Jonathan, "The Incidence of Mandated Maternity Benefits, American Economic Review, XXCIV (1994), forthcoming.

Health Care Financing Administration, "National Health Expenditures, 1988," Health Care Financing Review, XI (1990), 1-41.

Health Insurance Association of America, Source Book of Health Insurance Data. Washington, D.C.: HIAA. (1991).

Holmer, Martin, "Tax Policy and the Demand for Health Insurance," Journal of Health Economics III (1984), 203-221.

Katz, Lawrence F., and Kevin M. Murphy, "Changes in Relative Wages, 1963-1987: Supply and Demand Factors," Quarterly Journal of Economics, CVII (1992), 35-78.

Leibowitz, Arleen, and Michael Chernew, "The Firms' Demand for Health Insurance," in Health Benefits and the Workforce. Washington, D.C.: U.S. Department of Labor, (1992). 
Long, James E., and Frank A. Scott, "The Income Tax and Nonwage Compensation, " Review of Economics and Statistics, LXIV (1982), 211-219.

Marquis, M. Susan, and Stephen H. Long, "Worker Demand for Health Insurance in the NonGroup Market," mimeo, RAND corporation, (1993).

Marquis, M. Susan, and Charles E. Phelps, "Price Elasticity and Adverse Selection in the Demand for Supplementary Health Insurance, " Economic Inquiry, XXV (1987), 299-313.

Pauly, Mark, "Taxation, Health Insurance, and Market Failure in the Medical Economy," Journal of Economic Literature, XXIV (1986), 629-675.

Phelps, Charles E., The Demand for Health Insurance: A Theoretical and Empirical Investigation. Santa Monica, CA: RAND. (1973).

Phelps, Charles E., Health Economics. New York: Harper Collins. (1992).

Sloan, Frank, and Killard Adamche, "Taxation and the Growth of Nonwage Benefits," Public Finance Ouarterly, XIV (1986), 115-139.

Taylor, Amy, and Gail Wilensky, "The Effect of Tax Policies on Expenditures for Private Health Insurance," in Jack Meyer, ed., Market Reforms in Health Care: Current Issues, New Directions, Strategic Decisions. Washington, D.C.: American Enterprise Institute, (1983).

Thorpe, Kenneth, et al., "Reducing the Number of Uninsured by Subsidizing Employment-Based Health Insurance: Results from a Pilot Study, " Journal of the American Medical Association, CCLXVII (1992), 945-948.

Turner, Robert, "Are Taxes Responsible for the Growth in Fringe Benefits?," National Tax Journal, XL (1987), 205-220.

Vroman, Susan, and Gerard Anderson, "The Effect of Income Taxation on the Demand for Employer-Provided Health Insurance," Applied Economics, XVI (1984), 33-43.

Woodbury, Stephen A., "Substitution Between Wage and Nonwage Benefits," American Economic Review, LXIII (1983) 166-182.

Woodbury, Stephen A. and Daniel S. Hammermesh, "Taxes, Fringe Benefits, and Faculty," Review of Economics and Statistics, 287-296. 


\section{Endnotes}

1. See Pauly [1986] and Phelps [1992] for reviews of the literature on taxation and health insurance.

2. For example, the price variation used by Phelps [1973] comes from differences in firm size, which may be correlated with insurance demand due to the nature of workers who choose firms of different sizes. The price variation used by Leibowitz and Chernew [1992] and Marquis and Long (1993) comes from regional differences, which may also be correlated with demand differences.

3. Woodbury and Hamermesh [1992] surmount some of these problems by focusing on fringe benefit expenditures around the Tax Reform Act of 1986 for a panel of colleges. They cannot disentangle the income and price effects of the effects of a tax reform, however, and their methodology does not solve the problem of measurement error in the average campus tax rate.

4. Marquis and Phelps [1987] note that the applicability of evidence from the demand for supplemental insurance for evaluating the demand for traditional health insurance plans may be limited. Thorpe et al. [1992] note a number of potential problems with their experiment as well, such as a lack of information about the availability of the subsidy and the limited time for which it was offered. For a broader discussion of the applicability of the evidence from small scale experiments to broader policy changes, see Burtless and Orr [1985].

5. Some of the self-employed are likely to work in group settings, or participate in professional associations that offer group coverage. Among the single self-employed for whom we argue that tax reform should have the most pronounced effect, $40 \%$ of those with insurance have group health insurance coverage. For these individuals, identifying the marginal worker who decides to purchase insurance is again problematic.

6. That is, we assume that the price elasticity of demand for medical care is zero. In principle, one could increase the cost of insurance by a "moral hazard premium", but doing so requires drawing a judgement on the valuation of that extra medical care. The basic inferences that we draw here are robust to such a model. Our empirical analysis relaxes the assumptions on the copayment rate and price elasticity by using data on actual medical care expenditures.

7. $E\left\{M-\tau^{*} I^{*}(M-F)\right\}=1-\alpha \tau$, where I denotes an indicator variable for whether the taxpayer itemizes medical expenses, $M$ is medical expenses, and $F$ is again the floor below which medical expenses are not deductible.

8. In the limit, the only way to convincingly control for all such effects would be to fully model the underlying behavioral differences which drive tax rate differences, removing any useful variation from the cross-sectional model. Feenberg [1987] discusses the problems with cross-sectional tax price regressions for the case of charitable giving.

9. This is the essence of the "difference-in-difference" estimator employed by Angrist [1993], Card [1992], and Gruber [1994]. By using two different degrees of variation, spurious factors correlated with each degree of variation individually can be differenced away. 
10. We also explored a further restriction on the sample, to focus only on individuals who are heads of households. The results are very similar to those reported below for the full sample. Furthermore, we obtain similar results from both the CPS and an alternative data source which did not have this questionnaire change, as discussed below.

11. The 1989 CPS questionnaire provides reliable information on the nature of coverage. Among self-employed individuals with insurance coverage in the March 1989 survey, $61 \%$ had coverage in their own name. Among the single self-employed, however, the corresponding share was $93 \%$; for married self-employed, it was $55 \%$. Thus, our focus on the single self-employed should allow us to determine the effects of taxes on own coverage.

12. In results not reported, we examined two alternative definitions of self-employment: selfreported self-employment; and self-reported self-employment with more than $\$ 2000$ in selfemployment income and no wage income. The results are very similar to those reported below.

13. One anomalous result in Table 3 is the large increase in the probability of insurance coverage among self-employed individuals reporting very low incomes $(<\$ 5000)$. This group did not experience a large change the after-tax price of health insurance as a result of TRA86. This is a relatively small group, however, and the regressions below, which combine the information from different income classes, show that this group has little effect on the ultimate result.

14. The rotation design of the CPS survey results in approximately one-half of the sample being interviewed in consecutive Marches, so that one-quarter of our observations both before and after TRA ' 86 are repeated observations on the same individuals. Intra-personal correlation in insurance purchase behavior therefore implies that our standard errors are somewhat too small. However, even if these repeated observations add no independent information to our inferences, the standard errors should only be inflated by a factor of 1.15 .

15. Marginal probabilities are calculated as follows. For indicator variables, we predict the probability of coverage both if the dummy were equal to one, and again equal to zero, for the entire sample, and take the average of the differences in these predictions across individuals. For continuous variables, we predict the probability at the current level of the variable, and again at the current level plus one standard deviation, and take the average of the differences in the predictions across individuals.

16. This estimate is similar to that in studies of the quantity of insurance purchased by individuals such as Taylor and Wilensky [1983] and Holmer [1984], but lies below many of the findings using firm-level data, for example Phelps [1973], Woodbury [1983], and Woodbury and Hamermesh (1992).

17. More specifically, we create 150 detailed industry (50) by broad occupation class (3) cells, and assign each individual the average tax price for their cell; if the cell has less than 30 observations, we use the tax price for the entire industry.

18. Our analysis will focus on the absolute change in the difference between the insurance coverage rates for self-employed and employed workers. One could imagine alternative ways to measure the change in coverage, however, such as the difference in the percentage change in the 
coverage (or non-coverage) ratio. Our conclusion, that the tax subsidy to insurance purchase by the self-employed increased coverage among this group relative to other groups, is robust to alternative methods of measurement.

19. We estimate the self-employment rate in the CPS, beginning in 1982 , to be $7.8 \%, 8.1,7.6$, $7.2,7.5,7.8$, and $7.7 \%$ (1989). There are many explanations for the increase in the number of selfemployed, such as the fall in the top individual marginal tax rate to a level below the corporate rate, or the introduction of the health insurance tax subsidy itself.

20. This conclusion is derived by using the coefficients on the observable characteristics in our insurance demand equation to predict the expected level of demand in the self-employed population both before and after TRA86. The predicted rates are virtually identical across the two time periods.

21. We use the after-tax price for the self-employed only, rather than that for the entire sample, since we view the self-employed as providing information about the behavioral response to after-tax price changes, and the employed as controls for other economy-wide factors.

22. Furthermore, TRA86 includes a provision disqualifying self-employed individuals who are eligible for insurance coverage through a spouse from taking advantage of the tax subsidy. "Eligible" is not defined, however, and it is not clear whether this aspect of the rule is enforced. The average tax prices for the married and single samples differ only marginally relative to the estimated derivatives, so that it is reasonable to use the constant multiplier of 1.37 to derive the semielasticities.

23. Our estimated responses to TRA86 combine price effects on insurance demand as well as take-up effects for the health insurance subsidy. Tabulations using the NBER TAXSIM model show that less than half of self-employed tax filers in most income classes claimed the health insurance deduction. This suggests that our estimated effects on insurance coverage understate the price elasticity of demand for insurance coverage.

24. Individuals with family income between $\$ 20,000$ and $\$ 50,000$ are excluded from our estimates. Our estimates are similar if we simply split the sample at $\$ 50,000$, and the results below are not very sensitive to the cutoffs used.

25. We also computed this "difference in difference" estimator, comparing high-income and lowincome self employed, using the 1985 and 1988 SIPP data. Insurance rates among low-income workers appeared to increase more than those among high-income workers, in contrast to the CPS results, but the small number of self-employed SIPP respondents make it impossible to reject the hypothesis of substantial positive differential (as in the CPS) effects across income groups.

26. The three income categories are: for those with either employer-provided or non-employerprovided health insurance, $0-10,000,10-50,000$, and 50,000+; for those with no insurance, 0 $10,000,10-20,000$, and $20,000+$. The differences in categorization were constructed to ensure sufficient sample sizes in each cell. The family structure groups were: single; married, no children; 1 or 2 children; 3 or more children. 
Table I: Average After-Tax Price of Health Insurance

\begin{tabular}{ccc}
\hline \hline & Before TRA '86 & After TRA '86 \\
\hline Self-Employed & 1.410 & 1.334 \\
& {$[0.074]$} & {$[0.055]$} \\
Employed & 0.922 & 0.920 \\
& {$[0.045]$} & {$[0.045]$} \\
High Income & & \\
Self-Employed & 1.455 & 1.307 \\
& {$[0.065]$} & {$[0.041]$} \\
Low Income & & \\
Self-Employed & 1.389 & 1.355 \\
& {$[0.078]$} & {$[0.068]$} \\
High Income & & 0.902 \\
Employed & 0.900 & {$[0.029]$} \\
& {$[0.038]$} & 0.953 \\
Low Income & & {$[0.042]$} \\
Employed & 0.950 &
\end{tabular}

Notes. Figures are tax price of health insurance, based on authors calculations as described in Appendix A. Values in parentheses are standard deviations of estimated prices for individuals in each category. 
Table II: Characteristics of the Sample

\begin{tabular}{|c|c|c|c|c|c|}
\hline & $\begin{array}{c}\text { Employed } \\
\text { pre- } \\
\text { TRA86 }\end{array}$ & $\begin{array}{c}\text { Employed } \\
\text { post- } \\
\text { TRA86 }\end{array}$ & $\begin{array}{c}\text { Self-Emp } \\
\text { pre- } \\
\text { TRA86 }\end{array}$ & $\begin{array}{c}\text { Self-Emp } \\
\text { post- } \\
\text { TRA86 }\end{array}$ & $\begin{array}{c}\text { Working } \\
\text { Unins } \\
\text { pre-TRA86 }\end{array}$ \\
\hline Experience & 17.9 & 18.1 & 20.1 & 20.3 & 18.2 \\
\hline Education & 13.1 & 13.1 & 13.3 & 13.4 & 11.7 \\
\hline Female (\%) & 49.1 & 49.2 & 25.8 & 30.1 & 41.2 \\
\hline Married (\%) & 69.2 & 68.0 & 78.8 & 76.2 & 49.4 \\
\hline Nonwhite (\%) & 13.5 & 13.4 & 6.1 & 6.3 & 18.0 \\
\hline Working (\%) & 100 & 100 & 100 & 100 & 100 \\
\hline$<35$ hours $(\%)$ & 14.4 & 13.6 & 15.5 & 16.5 & 20.5 \\
\hline$<26$ weeks $(\%)$ & 11.0 & 9.6 & 5.1 & 4.9 & 19.2 \\
\hline $\begin{array}{c}\text { Family } \\
\text { income }(\$ 1985)\end{array}$ & 35839 & 36856 & 37852 & 39837 & 27641 \\
\hline $\begin{array}{l}\text { Management, } \\
\text { technician (\%) }\end{array}$ & 29.5 & 30.7 & 31.8 & 31.1 & 14.1 \\
\hline $\begin{array}{c}\text { Sales, } \\
\text { services (\%) }\end{array}$ & 39.8 & 39.1 & 30.0 & 31.1 & 41.0 \\
\hline Manual (\%) & 30.7 & 30.2 & 38.6 & 37.8 & 44.8 \\
\hline $\begin{array}{l}\text { Ag, mining, } \\
\text { construct. (\%) }\end{array}$ & 8.7 & 8.4 & 30.3 & 30.4 & 22.0 \\
\hline $\begin{array}{c}\text { Manufacturing } \\
(\%)\end{array}$ & 21.5 & 20.8 & 3.7 & 3.8 & 12.9 \\
\hline $\begin{array}{c}\text { Trade \& } \\
\text { services (\%) }\end{array}$ & 69.8 & 70.8 & 66.1 & 65.8 & 65.1 \\
\hline
\end{tabular}
text.

Notes. Figures are tabulted from the 1986-1990 CPS for 25-54 year olds, as described in 
Table III: Insurance Coverage, Self-Employment Status, and Income

\begin{tabular}{|c|c|c|c|c|c|c|}
\hline \multirow[b]{3}{*}{ Income } & \multicolumn{6}{|c|}{ Pre-TRA86 } \\
\hline & \multicolumn{2}{|c|}{ All } & \multicolumn{2}{|c|}{ Single } & \multicolumn{2}{|c|}{ Married } \\
\hline & SE & Empl & SE & Empl & SE & Empl \\
\hline $0-5 \mathrm{~K}$ & 30.0 & 36.0 & 23.7 & 35.4 & 39.7 & 38.9 \\
\hline $5-10 K$ & 38.3 & 51.7 & 38.8 & 53.5 & 38.0 & 46.3 \\
\hline $10-20 \mathrm{~K}$ & 55.4 & 80.0 & 48.0 & 83.7 & 59.0 & 74.8 \\
\hline $20-30 K$ & 71.9 & 92.4 & 57.4 & 94.3 & 75.0 & 91.4 \\
\hline $30-50 \mathrm{~K}$ & 81.3 & 96.5 & 68.7 & 95.6 & 82.9 & 96.6 \\
\hline $50 \mathrm{~K}+$ & 88.1 & 97.9 & 73.5 & 96.2 & 89.4 & 98.0 \\
\hline \multirow[t]{3}{*}{ Overall } & 69.4 & 87.9 & 50.0 & 80.1 & 74.7 & 91.4 \\
\hline & & & \multicolumn{2}{|c|}{ Post-TRA86 } & & \\
\hline & \multicolumn{2}{|c|}{ All } & \multicolumn{2}{|c|}{ Single } & \multicolumn{2}{|c|}{ Married } \\
\hline Income & SE & Empl & SE & Empl & SE & Empl \\
\hline $0-5 K$ & 33.5 & 30.9 & 29.9 & 30.0 & 42.9 & 35.3 \\
\hline $5-10 \mathrm{~K}$ & 39.1 & 45.5 & 38.0 & 47.7 & 40.8 & 38.1 \\
\hline $10-20 \mathrm{~K}$ & 57.2 & 74.3 & 50.7 & 79.8 & 61.0 & 66.0 \\
\hline $20-30 \mathrm{~K}$ & 73.6 & 88.9 & 59.2 & 92.0 & 77.7 & 87.2 \\
\hline $30-50 \mathrm{~K}$ & 84.3 & 95.2 & 68.8 & 94.5 & 86.5 & 95.3 \\
\hline $50 \mathrm{~K}+$ & 91.6 & 97.2 & 87.0 & 93.9 & 92.1 & 97.4 \\
\hline Overall & 73.3 & 84.9 & 53.4 & 76.3 & 79.5 & 88.9 \\
\hline
\end{tabular}

Notes. SE denotes self-employed. Figures are average percent $p$ rivately insurance for the cell labelled on the axes. Means tabulated from the March 1986, 1987, 1989, and 1990 CPS. PreTRA86 is calendar years 1985 and 1986; post-TRA86 is calendar years 1988 and 1989. Selfemployed defined as self-reported, with at least $\$ 2000$ in self-employment income. Employed is non self-reported self-employed, no self-employment income, and at least $\$ 2000$ in wage and salary income. 
Table IV: Aggregate Insurance Rates, Employed and Self-Employed, 1982-1989

\begin{tabular}{|c|c|c|}
\hline Year & Self-Employed & Employed \\
\hline 1982 & 68.9 & 88.6 \\
\hline 1983 & 72.0 & 88.9 \\
\hline 1984 & 68.9 & 88.1 \\
\hline 1985 & 68.6 & 88.0 \\
\hline 1986 & 70.1 & 88.0 \\
\hline 1987 & 76.1 & 86.8 \\
\hline 1988 & 73.2 & 86.1 \\
\hline 1989 & 73.5 & 84.5 \\
\hline
\end{tabular}


Table V: Probit Estimates of Insurance Demand Models

\begin{tabular}{|c|c|c|c|c|}
\hline$=$ & (1) & $\begin{array}{c}\text { (2) } \\
\text { Marg Probs } \\
\text { for estimates } \\
\text { in col (1) }\end{array}$ & (3) & $\begin{array}{c}\text { (4) } \\
\text { Grouped }\end{array}$ \\
\hline $\begin{array}{l}\text { Experience } \\
\qquad(* 10)\end{array}$ & $\begin{array}{c}0.060 \\
(0.005)\end{array}$ & 0.100 & $\begin{array}{c}0.062 \\
(0.005)\end{array}$ & $\begin{array}{c}0.062 \\
(0.005)\end{array}$ \\
\hline Education & $\begin{array}{c}0.067 \\
(0.002)\end{array}$ & 0.011 & $\begin{array}{c}0.067 \\
(0.002)\end{array}$ & $\begin{array}{c}0.065 \\
(0.002)\end{array}$ \\
\hline Female & $\begin{array}{c}0.099 \\
(0.009)\end{array}$ & 0.017 & $\begin{array}{c}0.101 \\
(0.010)\end{array}$ & $\begin{array}{c}0.095 \\
(0.009)\end{array}$ \\
\hline Married & $\begin{array}{c}-0.014 \\
(0.010)\end{array}$ & -0.002 & $\begin{array}{c}0.024 \\
(0.010)\end{array}$ & $\begin{array}{l}-0.025 \\
(0.010)\end{array}$ \\
\hline Nonwhite & $\begin{array}{c}-0.171 \\
(0.011)\end{array}$ & -0.031 & $\begin{array}{c}-0.169 \\
(0.011)\end{array}$ & $\begin{array}{c}-0.169 \\
(0.011)\end{array}$ \\
\hline $\begin{array}{c}<35 \\
\text { hours/wk }\end{array}$ & $\begin{array}{c}-0.222 \\
(0.014)\end{array}$ & -0.041 & $\begin{array}{l}-0.213 \\
(0.014)\end{array}$ & $\begin{array}{l}-0.216 \\
(0.014)\end{array}$ \\
\hline $\begin{array}{c}<18 \\
\text { hours/wk }\end{array}$ & $\begin{array}{c}0.063 \\
(0.031)\end{array}$ & 0.011 & $\begin{array}{c}0.064 \\
(0.031)\end{array}$ & $\begin{array}{c}0.062 \\
(0.031)\end{array}$ \\
\hline $\begin{array}{c}<26 \\
\text { weeks/yr }\end{array}$ & $\begin{array}{c}-0.314 \\
(0.015)\end{array}$ & -0.060 & $\begin{array}{l}-0.306 \\
(0.015)\end{array}$ & $\begin{array}{l}-0.313 \\
(0.015)\end{array}$ \\
\hline $\begin{array}{l}\log \operatorname{tax} \text { unit } \\
\text { income }\end{array}$ & $\begin{array}{c}0.801 \\
(0.008)\end{array}$ & 0.095 & $\begin{array}{c}0.731 \\
(0.009)\end{array}$ & $\begin{array}{c}0.797 \\
(0.008)\end{array}$ \\
\hline $\begin{array}{c}\text { Self- } \\
\text { employed }\end{array}$ & $\begin{array}{c}-0.526 \\
(0.014)\end{array}$ & -0.108 & $\begin{array}{r}0.116 \\
(0.047)\end{array}$ & $\begin{array}{c}0.522 \\
(0.071)\end{array}$ \\
\hline After-tax Price & & & $\begin{array}{l}-1.459 \\
(0.103)\end{array}$ & $\begin{array}{l}-2.369 \\
(0.158)\end{array}$ \\
\hline Derivative & & & -0.263 & -0.443 \\
\hline
\end{tabular}

Notes. Columns (1), (3) and (4) report estimates of probit equations, and include four year dummies and 15 industry dummies. Numbers in parentheses are standard errors. For column (1), column (2) inteprets the marginal probability derivatives. In other columns, marginal probability derivative for tax price is interpreted in the elasticity row. All regressions have 187,111 observations 
Table VI: Illustration of Differences-in-Differences for Price Derviate Estimates Self-Employed versus Employed

\begin{tabular}{cccc}
\hline \hline Group/Year & $1985-6$ & $1988-9$ & $\begin{array}{c}\text { Time Difference } \\
\text { w/in Group }\end{array}$ \\
Self-Employed & & & 0.040 \\
$\left(\mathrm{~N}_{1985-6}=6786, \mathrm{~N}_{1988-9}=7306\right)$ & $(0.006)$ & $(0.005)$ & $(0.008)$ \\
& & & \\
Employed & 0.880 & 0.853 & -0.027 \\
$\left(\mathrm{~N}_{1985-6}=85685, \mathrm{~N}_{1988-9}=88562\right)$ & $(0.001)$ & $(0.001)$ & $(0.002)$ \\
Group Diff & -0.186 & -0.119 & \\
at a Point in Time & $(0.006)$ & $(0.005)$ & \\
& & & \\
& & Difference-in- & \\
& & Difference & $(0.067$ \\
& &
\end{tabular}

Notes. Numbers in first row of each cell is mean percent privately insured; number in parentheses is standard error on estimate. Sample sizes for each cell are presented under row headings. Data tabulated from March CPS. 
Table VII: "Differences in Differences" Estimates of Insurance Demand

\begin{tabular}{cccc}
\hline & All & Single & Married \\
\hline & \multicolumn{4}{c}{$\begin{array}{c}\text { Diff-in-Diff - } \\
\end{array}$} & Self-Employed versus Employed $\left(\delta_{3}\right.$ in equation (5)) & \\
\hline Probit & 0.236 & 0.232 & 0.261 \\
Coefficient & $(0.026)$ & $(0.050)$ & $(0.031)$ \\
Marginal & 0.037 & 0.049 & 0.033 \\
Probability & & & \\
Implied & -0.500 & -0.620 & -0.440 \\
Elasticity & & & \\
\hline
\end{tabular}

Diff-in-Diff -

High Income vs. Low Income Self-Employed $\left(\delta_{3}\right.$ in equation (6))

\begin{tabular}{|c|c|c|c|}
\hline $\begin{array}{l}\text { Probit } \\
\text { Coefficient }\end{array}$ & $\begin{array}{c}0.148 \\
(0.075)\end{array}$ & $\begin{array}{c}0.538 \\
(0.192)\end{array}$ & $\begin{array}{r}0.098 \\
(0.085)\end{array}$ \\
\hline $\begin{array}{l}\text { Marginal } \\
\text { Probability }\end{array}$ & 0.042 & 0.186 & 0.025 \\
\hline $\begin{array}{l}\text { Implied } \\
\text { Elasticity }\end{array}$ & -0.368 & -2.188 & -0.216 \\
\hline
\end{tabular}

\section{Diff-in-Diff-in-Diff:}

High Income vs. Low Income Self-Employed vs.

High Income vs. Low Income Employed $\left(\delta_{7}\right.$ in equation (7))

$\begin{array}{cccc}\text { Probit } & 0.135 & 0.730 & -0.008 \\ \text { Coefficient } & (0.082) & (0.227) & (0.094) \\ \text { Marginal } & 0.028 & 0.170 & -0.001 \\ \text { Probability } & & & \\ \text { Implied } & -0.248 & -1.270 & 0.008 \\ \text { Elasticity } & & & \end{array}$

Notes. Each panel reports probit coefficients and standard errors from regressions such as equations (5), (6), and (7)in the text; marginal probability derivatives, calculated as described in text; and implied elasticities, which are calculated by dividing the marginal probabilities by the appropriate difference-in-difference in tax rates. All regressions include the set of control variables described in Table 5. 

3 9080008462043
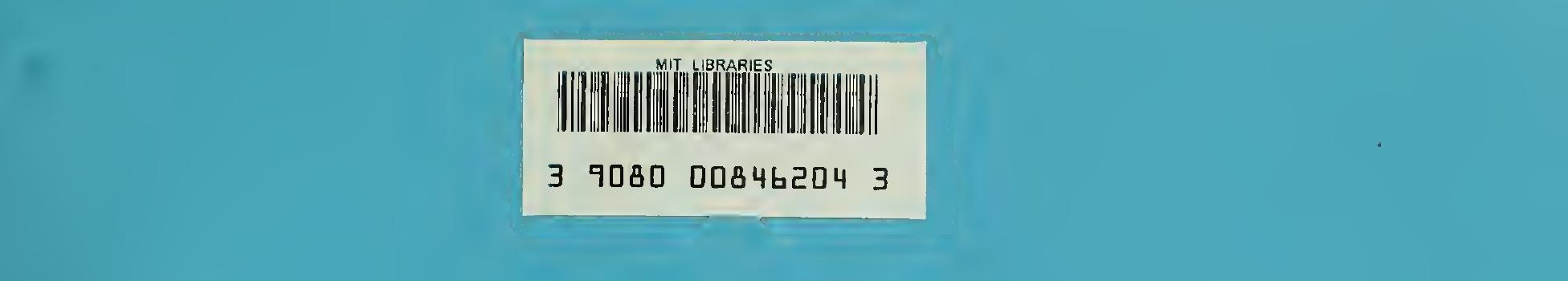




$$
7
$$



